\title{
Conditions of blended learning implementation in H. S. Skovoroda Kharkiv National Pedagogical University: experience of Physics and Mathematics Faculty
}

\author{
Nataliia Ponomarova ${ }^{1, *}$, Olena Gulich ${ }^{1, * *}$, Oksana Zhernovnykova ${ }^{1, * * *}$, Nadiia Olefirenko ${ }^{1, * * * *}$, and Vitalii Masych ${ }^{1, \dagger}$ \\ ${ }^{1}$ H. S. Skovoroda Kharkiv National Pedagogical University, 29 Alchevskyh Str., Kharkiv, 61002, Ukraine
}

\begin{abstract}
The entire education system of Ukraine in the realities of the COVID-19 pandemic in 2020 found itself in a situation of the challenge for the immediate implementation of distance learning in educational institutions of all levels. Despite the presence of a relatively large number of scientific studies on the features of distance education, they were not enough for its practical implementation. A blended form of learning requires a combination of asynchronous and synchronous modes of distance learning, finding optimal tools and ways to interact with students, adapting traditional methods of studying disciplines to new conditions, overcoming inequality of participants in the educational process in technical support, mastering digital technologies. Analysis of the experience of the Faculty of Physics and Mathematics at H. S. Skovoroda Kharkiv National Pedagogical University showed that the conditions for the introduction of blended learning in institutions of higher pedagogical education are: advanced training and appropriate retraining of teaching staff; building a model of blended learning as a starting point for distance learning; development of educational and methodical support of educational disciplines taking into account the requirements of blended learning; implementation of all elements of the educational process in blended learning; providing participants of the educational process with organizational, methodological, technical and psychological support.
\end{abstract}

\section{Introduction}

The entire education system of Ukraine in the realities of the COVID-19 pandemic in 2020 found itself in a situation of challenge for the immediate introduction of distance education in educational institutions of all levels [1-5].

Distance learning is one of the forms of learning that emerged and improved with the development of Internet technologies, and today has highlighted characteristics, principles and a number of theoretical and practical developments [6-21].

The organization of high-quality mass distance learning in higher education institutions is a complex and multifactorial process, which is now at the beginning of formation and development.

Despite the presence of a relatively large number of scientific studies on the features of distance education, they were not enough for its practical implementation.

\section{Scientific investigations in the field}

In the context of the COVID-19 pandemic, the organization of the educational process in higher education, including pedagogy, has undergone significant changes. Thus,

\footnotetext{
*e-mail: ponomna@gmail.com

**e-mail: gulich.elena@gmail.com

***e-mail: oazhernovnykova@gmail.com

****e-mail: olefirenkonn@gmail.com

†e-mail: masych@hnpu.edu.ua
}

from September 1, 2020, the Ministry of Education and Science of Ukraine provided recommendations on the introduction of blended learning in institutions of professional higher and higher education [22-24].

Let's turn to the experience of foreign countries, where the organization of the educational process in universities on the basis of blended learning has been operating for a long time. It should be noted that blended learning is now popular because it has proven to be an effective approach to organizing the modern educational process, while adding value to a specially designed learning environment through the inclusion of online learning resources. Despite this growing interest, controversy continues over the definition of blended learning. As a result, teachers of higher education institutions understand this term differently, and evolve different approaches to the design of this educational process [25-28].

It should be noted that blended learning is the most effective method of teaching in education, especially in higher education. Blended learning pedagogy is based on the assumption that direct interaction has significant advantages, as well as on the understanding that the use of online teaching methods contributes to the formation of a high level of knowledge [29]. Blended learning is a mixture of traditional face-to-face and online learning, so learning takes place both in the classroom and online. It is important to note that the online component becomes a natural continuation of traditional learning in the class- 
room [30]. Based on the analysis of scientists, it is proved that blended learning is a new trend that provides significant benefits to students $[31,32]$.

In modern conditions, one of the best reasons for developing blended courses is that they ensure the viability of students who seek not only the flexibility of distance learning courses, but also want to have some personal contact with teachers and other students in the classroom. Blended learning transcends time, local, and cultural barriers and has created many enhanced opportunities for students and faculty $[33,34]$. Therefore, blended learning represents a new educational paradigm [35].

The classification of approaches proposed by A. Alammary, J. Sheard, A. Carbone is important for our study. Researchers have distributed the impact of blended learning at high, medium and low levels on the potential of curricula and their effectiveness in blended learning. The obtained positive results provided an opportunity for scientists to provide recommendations on when and how to use pedagogical approaches in the organization of blended learning [36].

According to N. Vernadakis, M. Giannousi, V. Derri, M. Michalopoulos, E. Kioumourtzoglou, blended learning environment is a hybrid of learning and online learning that includes some convenience of online courses without complete loss of personal preference. In their article, the researchers explored the impact of traditional and blended learning on students' achievements. Based on the results obtained, blended learning looks like an alternative teaching practice that should be adopted to help students improve their results [37].

Thus, M. J. Kintu, S. Zhu, E. Kagambe in their study through the analysis established the relationship between the psychological characteristics of students, the prerequisites of a specially created educational environment and learning results. The conclusion of scientist' multiple regression analysis have shown that effective organization of the educational process on the basis of blended learning involves using effective technology, online tools and personal support for each student [38]. This aspect was studied by $\mathrm{O}$. Zhernovnikova, where the scientist singled out the psychological aspect of the implementation of distance learning technologies in the educational process of future teachers of mathematics on the basis of blended learning [39], and also defined the system of knowledge, skills conditions of blended learning [40].

A group of scientists from India are convinced that blended learning is a positive result of advanced learning technologies. The blended learning model for higher education proposed by scientists, where traditional lectures were taught only through e-learning, was successful for students because it was effectively adapted to the educational process [41].

Another group of scholars provides the results of their research on how teachers and students in the educational process can use the ePortfolio platform as a tool. Thus, A. G. Ambrose, H. L. Chen quite successfully integrated e-portfolios into counseling and mentoring programs [42].
The purpose of the article is to establish the conditions of blended learning implementation in institutions of higher pedagogical education.

\section{Research results}

2020 turned out to be a de facto crucial year for $\mathrm{H}$. S. Skovoroda Kharkiv National Pedagogical University (KhNPU) for mastering and implementing distance and blended forms of education. Thus, in the spring semester of 2019-2020 at the Faculty of Physics and Mathematics a number of events were carried out:

- lectures and practical classes in mathematics, physics, computer science and psychological and pedagogical disciplines were deployed in full according to the schedule online;

- it was organized the implementation of Laboratory works in physical and computer science disciplines by students in virtual environments, their online broadcasts and video recordings were performed;

- all introductory and reporting conferences on pedagogical practices were held online;

- the defenses of term papers for all courses and specialties in accordance with the curriculum were organized online ;

- the examination session took place, and students of the final bachelor's course confidently passed the state certification;

- the creation of full-fledged distance courses on the Moodle LMS in accordance with the needs of the educational process has begun (figure 1).

At the same time, the participants of the educational process faced a number of objective and subjective difficulties.

First of all, all employees had to master extremely quickly and at a high level only the latest digital competencies, as well as essentially innovative approaches to creating new models of learning.

The introduction of distance education for a long time is in the field of research interests of the teaching staff of the Physics and Mathematics Faculty and is reflected in the topics of dissertation researches, master's theses, term papers and other researches.

However, the retraining and advanced training of teachers and staff in the implementation of distance learning has begun since the spring semester.

Thus, all teachers of the Faculty have registered and in accordance with the registration schedule are internships of pedagogical and scientific-pedagogical staff of higher education institutions in distance education, organized on the basis of the Department of Information Technology of KhNPU. In addition, teachers of our faculty participate in online internships, courses, webinars, etc. on relevant topics with the receipt of certificates. We will especially note the online course "On distance and blended learning formats" for teachers and school leaders (project of the Ministry of Education and Science of Ukraine on the EdEra 


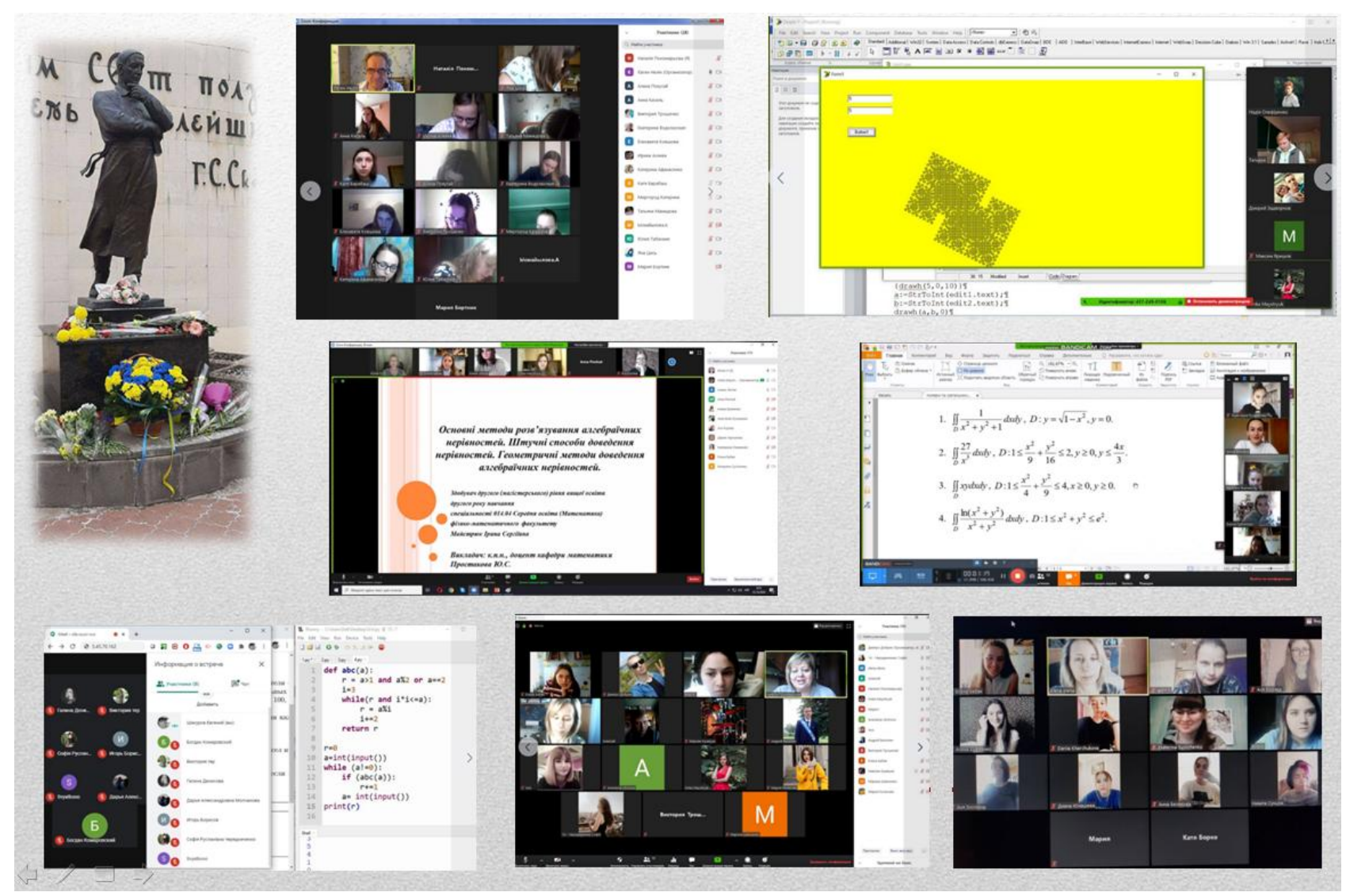

Figure 1. Online classes at the Faculty of Physics and Mathematics

platform), online refresher courses "Cloud technologies in distance learning in quarantine" (based on Zhytomyr Polytechnic State University), international training (webinars) "Cloud services for online learning on the example of the platform Zoom".

During the period from April to November 2020, 19 employees of the faculty received 45 certificates of advanced training in the relevant field (figure 2).

According to experts, distance learning is an organization of the educational process in which participants are distant from each other and interact using digital technologies.

For synchronous interaction, our teachers have mastered such popular platforms as Zoom, Microsoft Teams, Google Meet and others. Platforms such as Google Classroom, Edmodo, Moodle and other were used for asynchronous interaction of participants of the educational process at the faculty. Since the spring semester, the only reference point at the Faculty of Physics and Mathematics has been Moodle LMS. All teachers and students of the faculty are registered on the platform, have free access to it. Note that for the implementation of distance learning you also need to master special tools: electronic interactive whiteboard services, electronic resources for creating video lectures and collections of materials, to test knowledge and skills, creating quizzes, crosswords, puzzles, to create online demonstrations and simulations, tapes time, mind maps, etc.
From October 2020, due to quarantine restrictions, a blended form of education was introduced at the Faculty of Physics and Mathematics.

Blended form of education involves the organization of the educational process that combines distance and fulltime learning (the use of distance learning technologies in full-time form).

Understanding blended learning as a learning model that provides students with certain elements of control over the study of the material and the ability to personalize learning, opens up much broader prospects for its effectiveness. The basis for the effective use of blended learning is the technological readiness of teachers, students and educational institutions, as well as a thorough methodological training of each discipline. It should be borne in mind that there are different models for the implementation of blended learning: rotary, flexible, selfblending, in-depth virtual. Blended learning is effective due to the complete adaptation to specific learning conditions, features of educational material and even the needs of a particular group. Therefore, depending on the capabilities of teachers and the capabilities of students within different disciplines, teachers choose the model that best helps to achieve learning results.

Accordingly, the content of distance learning courses on the Moodle LMS should be developed to support blended learning. 


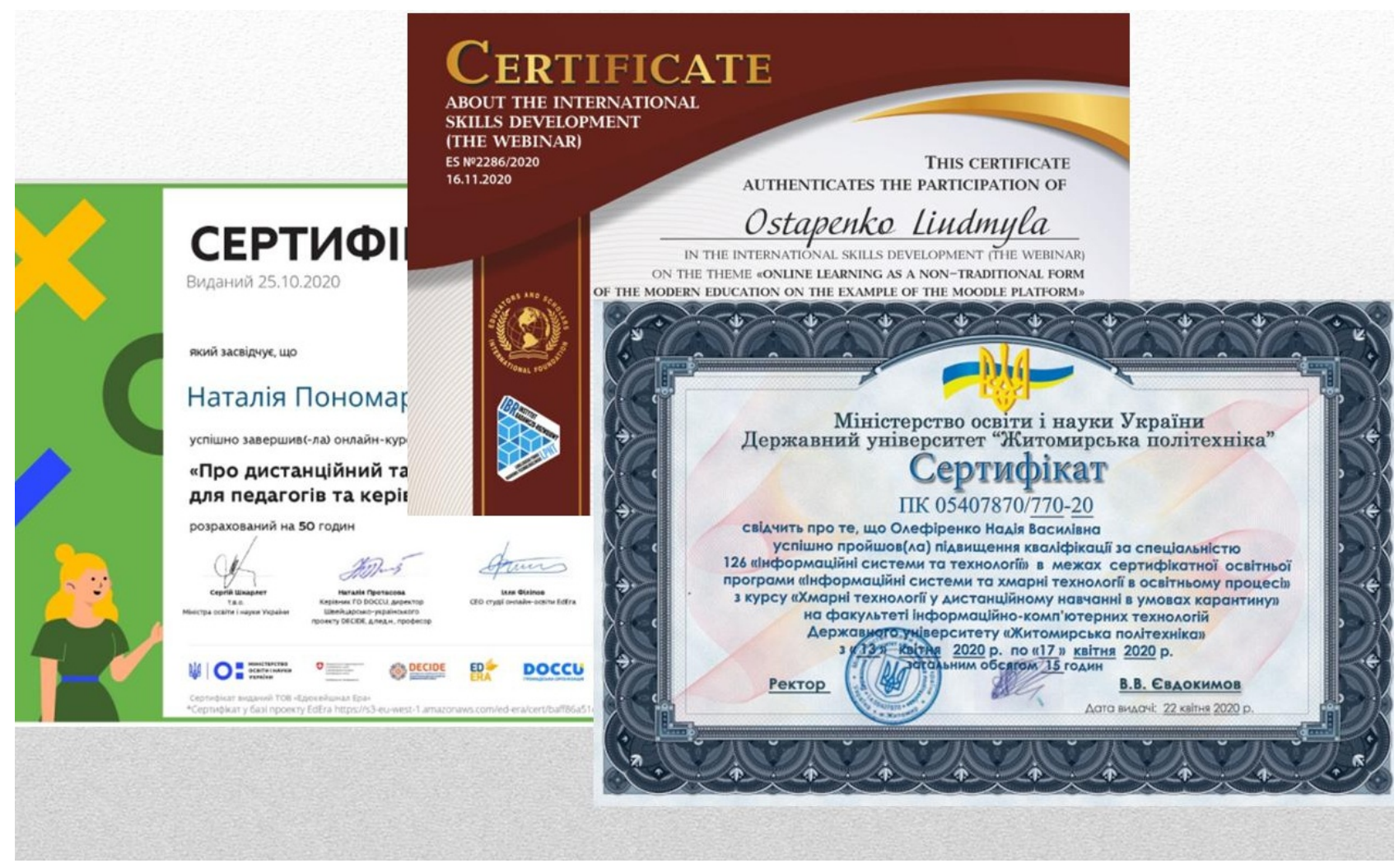

Figure 2. Examples of teachers' certificates

Educational material in various formats (texts, presentations, separate videos), materials for testing and questioning for tests and exams, etc. are focused not on creating independent distance courses, but on supporting the combination of synchronous and asynchronous mode of work, online and offline forms teaching.

As of December 1, 2020, a total of 159 courses of the departments of the Faculty of Physics and Mathematics at different stages of their development are presented on Moodle.

During the first semester of 2020-2021 academic year, the graduating departments of the Physics and Mathematics Faculty provide teaching of 66 disciplines (Department of Physics and Cyberphysical Systems - 16, Department of Mathematics - 31, Department of Informatics - 19), and the Department of Pedagogy - 21 disciplines for each which created and completed courses on Moodle LMS.

The scientific-methodical commission of the Faculty with the participation of the dean's office audited the content of the distance courses according to the following criteria: availability and quality of course summary (open summary of the course), work program, structured course by topics, lectures, assignments for practical or laboratory work, references.

The list of these audit criteria was discussed, established and approved by the Council of the Faculty of Physics and Mathematics. This list correlates with the list of requirements for distance learning courses proposed by the university management, while taking into account the needs of the blended form of education [43].
For example, the plan (course presentation, course structure information, learning algorithm) was excluded from the list of criteria at the internal audit stage as one that is inherent in the mostly asynchronous distance form.

As for the criterion of quality of educational material, it has its special weight and significance, therefore, if we do not take into account the purely technical requirements, in our opinion, its establishment requires a very careful expert assessment.

Courses were assessed by the degree of criterion's detection ( 0 - absent, 1 - entry level, 2 - intermediate level, 3 - high level).

According to the results of the audit, we obtained data that showed significant changes in the content of distance learning courses, compared to the previous semester. The analysis of the obtained data became the basis for setting benchmarks for further qualitative improvement of distance learning courses. The audit was an impetus to intensify the work of teachers on the courses, contributed to the exchange of departmental and personal experience of employees, the growth of their professional skills (table 1).

Thus, teachers place the following necessary components of distance courses on Moodle platform:

- work programs, syllabuses, course presentations, bibliography (with links to external resources, official websites and the university repository), etc;

- glossaries with full-text search and auto-binding;

- lecture materials on each topic, presentations and videos to them; 
Table 1. Results of the audit of distance learning courses (percentage of courses with maximum score by criterion)

\begin{tabular}{llllllll}
\hline Department & Course & Summary & Work program & Structure & Lecture & Tasks & References \\
\hline Physics & 16 & 75.00 & 68.75 & 81.25 & 68.75 & 87.5 & 87.50 \\
Mathematics & 31 & 80.65 & 48.39 & 58.06 & 67.74 & 70.97 & 70.97 \\
Informatics & 18 & 88.89 & 50.00 & 100.00 & 83.33 & 88.89 & 77.78 \\
Pedagogy & 21 & 52.38 & 95.24 & 80.95 & 95.24 & 95.24 & 90.48 \\
\hline
\end{tabular}

- materials to ensure different types of student activities: lesson, seminar, test, form, resource, tasks and others;

- materials for independent work;

- tasks for control in the form of modular tests and for self-control in the form of homework and test tasks;

- final control (exam or test).

The following courses deserve special attention, which are complete and original, the creative approach of teachers to the organization of distance learning (figure 3):

- "Pedagogy" (L. M. Kalashnikova and A. V. BoyarskayaKhomenko, second year, Faculty of Physics and Mathematics, 50 classroom hours);

- “Object-oriented programming” (N. V. Olefirenko, second year, group 2I, 60 classroom hours);

- "General Physics and Astronomy" (V. V. Masych, third year, group 3M, 38 classroom hours);

- "Linear Algebra" (Y. S. Prostakova, first year, group $1 \mathrm{M}, 60$ classroom hours).

The technology of students' work on mastering academic disciplines in the conditions of blended learning with the use of distance courses at Moodle LMS provides:

- acquaintance of students with educational and methodical maintenance of discipline (educational and working program, quantity of lectures and practical employments, volume of material for independent studying and forms of reporting);

- consistent study by students of educational material distributed by meaningful modules. At the same time, during full-time study there is a main presentation and discussion of educational material (students who missed classes for good reasons, have the opportunity to read the syllabus, downloading it from the relevant section of the course). During the online training, the lesson is held in synchronous mode, followed by the placement of the processed materials (usually a presentation made in the PowerPoint) on the Moodle platform. Thus, students have the opportunity to continue the study on their own after discussing the material with the teacher, or to review individual parts of the lesson to better master some issues or when doing homework;

- performance by students of homework and tasks for control and independent works and their placement in the corresponding sections on Moodle LMS. This allows you to conveniently monitor the dynamics of students' performance of relevant work, to give grades and store information about the points, to maintain contact with students and to respond in a timely manner and make adjustments to the learning process in case of problems.
In the conditions of blended learning it is important to ensure the implementation of all types of practices pedagogical practice in general secondary education institutions, in institutions of specialized secondary education, in higher education institutions, scientific and pedagogical practice (figure 4).

The introduction of distance learning does not bypass the educational work with students as an integral part of the educational process, which is extremely important for the professional training of teachers-to-be. During the year, students of the Faculty of Physics and Mathematics not only actively participated in university-wide online events, but were also the initiators of some of them. Particularly popular were the projects "Stay at home", "Easter", online competition "StudVesna-2020, OnlineFest", "Home University", "Do not stay indifferent", "Keep fit! Train at home!", "Healthy lifestyle", an online concert dedicated to the Day of the Education Worker, an online week of pedagogy and many others. The introduction of quarantine measures has activated and strengthened the importance of the work of academic group curators: they systematically hold briefings on distance learning, online meetings. At the beginning of the spring distance session, under the initiative of the academic group curators of the Faculty the flash mob "It's easy if together!" aiming to support students was held.

Student's research activities take place online as part of the professional training of teachers-to be. On November 24 and 25, 2020, the Faculty of Physics and Mathematics hosted the XVIII scientific-methodical conference of higher education students "Naumovsky readings", which worked in five sections: mathematical studies (theory and practice, history and comparative studies), innovative technologies in educational practice, physics and cyberphysical systems, educational, pedagogical sciences. About 90 participants from 12 higher education institutions of Ukraine took part in the conference.

\section{Discussion and conclusions}

Blended form of learning requires a combination of asynchronous and synchronous modes of distance learning, finding optimal tools and ways to interact with students, adapting traditional methods of studying disciplines to new conditions, overcoming inequality of participants in the educational process in technical support, mastering digital technologies.

Analysis of the experience of the Faculty of Physics and Mathematics of KhNPU showed that the conditions for the introduction of blended learning in institutions of higher pedagogical education are: 


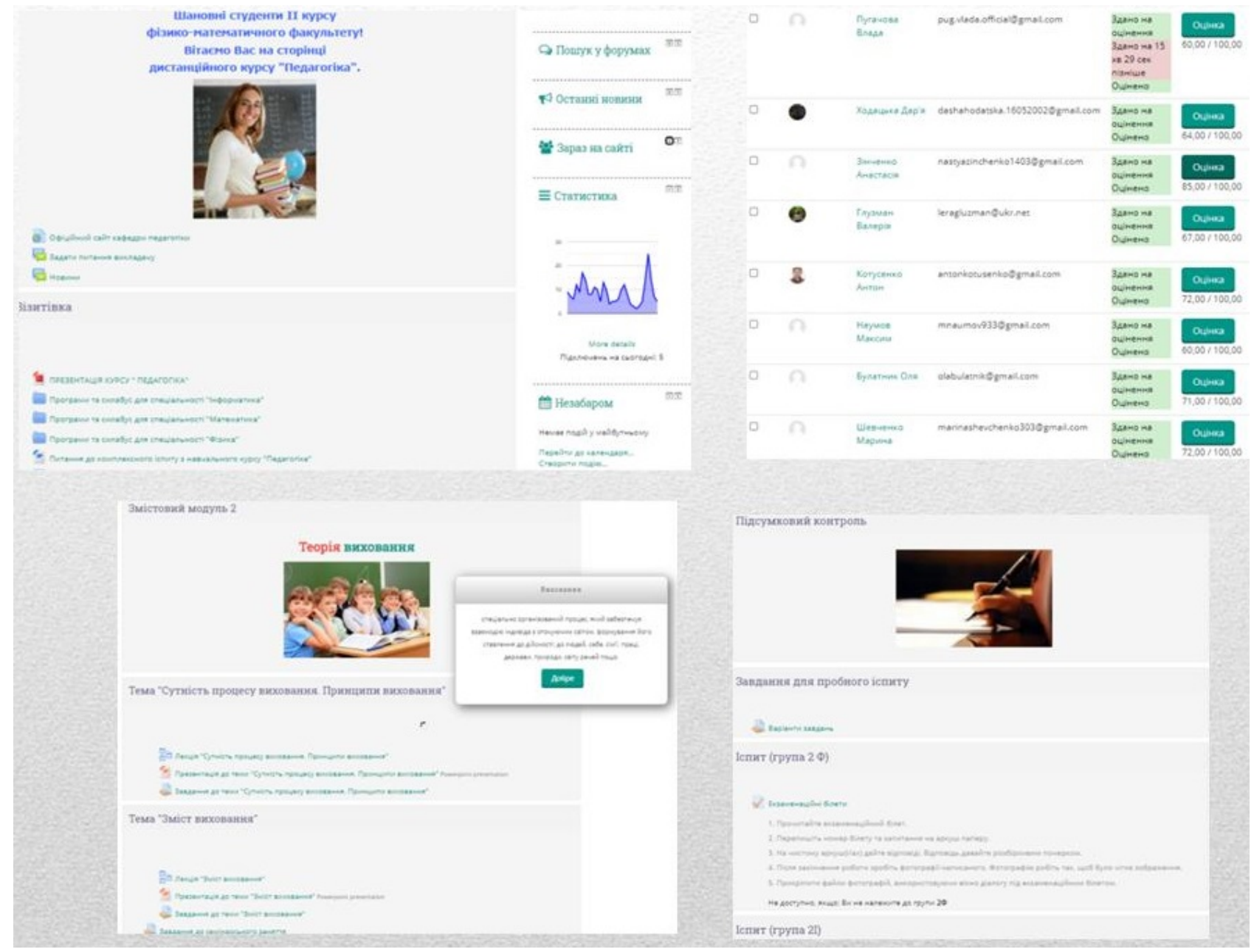

Figure 3. Examples of course materials
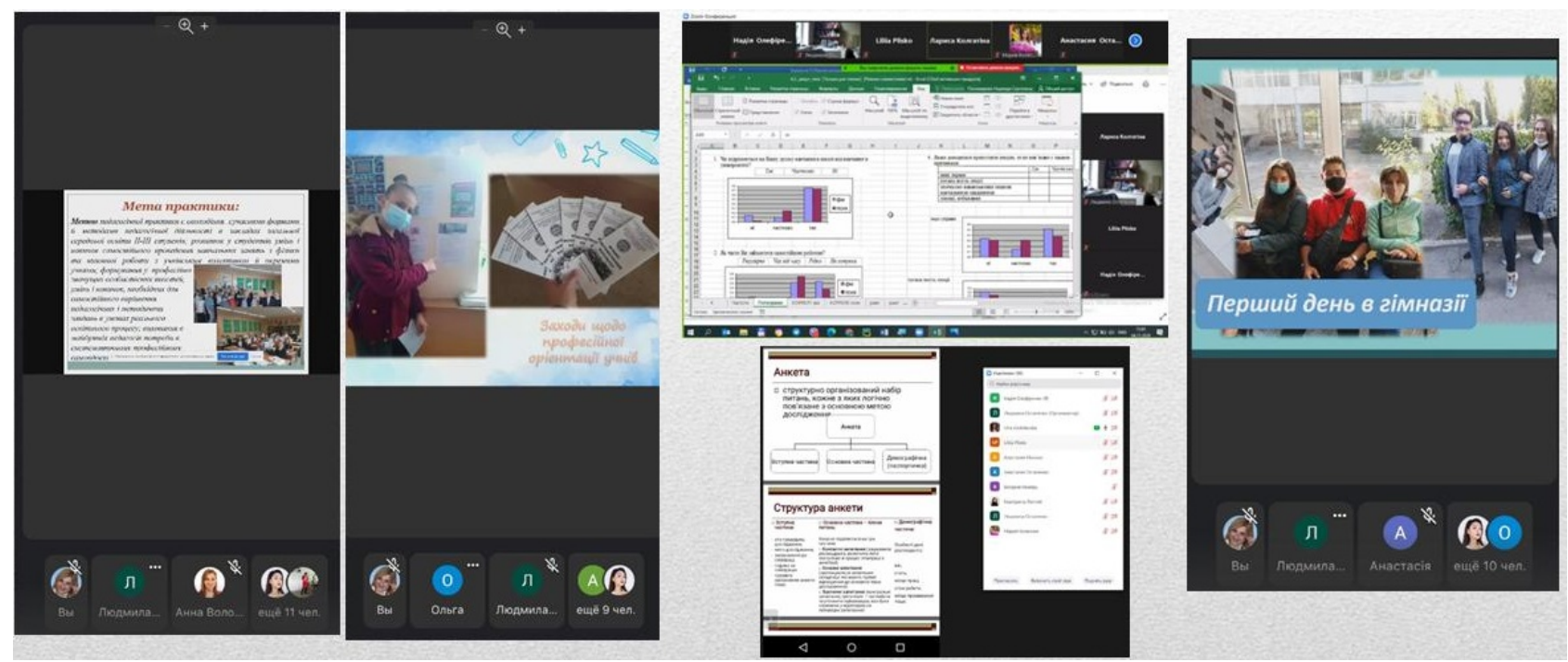

Figure 4. Online report on pedagogical practice 
- advanced training and appropriate retraining of teaching staff;

- building a model of blended learning as a starting point for blended learning;

- development of educational and methodical support of educational disciplines taking into account the requirements of blended learning;

- coverage in blended learning of all elements of the educational process;

- providing participants of the educational process with organizational, methodological, technical and psychological support.

\section{References}

[1] O. Burov, A. Kiv, S. Semerikov, A. Striuk, M. Striuk, L. Kolgatina, I. Oliinyk, CEUR Workshop Proceedings 2731, 1 (2020)

[2] S. Semerikov, S. Chukharev, S. Sakhno, A. Striuk, V. Osadchyi, V. Solovieva, T. Vakaliuk, P. Nechypurenko, O. Bondarenko, H. Danylchuk, E3S Web of Conferences 166 (2020)

[3] K. Polhun, T. Kramarenko, M. Maloivan, A. Tomilina, Journal of Physics: Conference Series 1840, 012053 (2021)

[4] N.S. Ponomareva, Journal of Physics: Conference Series 1840, 012035 (2021)

[5] M. Velykodna, Psychodynamic Practice 27, 10 (2021)

[6] E. Kozlovsky, H. Kravtsov, CEUR Workshop Proceedings 2168, 42 (2017)

[7] A. Prokhorov, I. Klymenko, E. Yashina, O. Morozova, S. Oleynick, T. Solyanyk, CEUR Workshop Proceedings 1844, 245 (2017)

[8] O. Hniedkova, CEUR Workshop Proceedings 2104, 447 (2018)

[9] L. Havrilova, O. Ishutina, V. Zamorotska, D. Kassim, CEUR Workshop Proceedings 2433, 429 (2019)

[10] V. Kukharenko, T. Oleinik, CEUR Workshop Proceedings 2393, 156 (2019)

[11] L. Kravtsova, N. Kaminska, H. Kravtsov, CEUR Workshop Proceedings 2732, 1187 (2020)

[12] N. Kushnir, N. Osypova, N. Valko, L. Kuzmich, CEUR Workshop Proceedings 2732, 1152 (2020)

[13] S. Shokaliuk, Y. Bohunenko, I. Lovianova, M. Shyshkina, CEUR Workshop Proceedings 2643, 548 (2020)

[14] M. Syvyi, O. Mazbayev, O. Varakuta, N. Panteleeva, O. Bondarenko, CEUR Workshop Proceedings 2731, 369 (2020)

[15] A. Tarasov, I. Getman, S. Turlakova, I. Stashkevych, S. Kozmenko, CEUR Workshop Proceedings 2643, $161(2020)$

[16] V. Yahupov, V. Kyva, V. Zaselskiy, CEUR Workshop Proceedings 2643, 71 (2020)

[17] D.Y. Bobyliev, E.V. Vihrova, Journal of Physics: Conference Series 1840, 012002 (2021)
[18] N.P. Franchuk, T.V. Prydacha, Journal of Physics: Conference Series 1840, 012054 (2021)

[19] I. Lénárt, Journal of Physics: Conference Series 1840, 012003 (2021)

[20] T.A. Vakaliuk, O.M. Spirin, N.M. Lobanchykova, L.A. Martseva, I.V. Novitska, V.V. Kontsedailo, Journal of Physics: Conference Series 1840, 012051 (2021)

[21] I.S. Zinovieva, V.O. Artemchuk, A.V. Iatsyshyn, Y.O. Romanenko, O.O. Popov, V.O. Kovach, D.V. Taraduda, A.V. Iatsyshyn, Journal of Physics: Conference Series (2021, in press)

[22] Rekomendatsii shchodo vprovadzhennia zmishanoho navchannia u zakladakh fakhovoi peredvyshchoi ta vyshchoi osvity (2020), https://mon.gov. ua/storage/app/media/vishcha-osvita/ 2020/zmyshene20navchanny/ zmishanenavchannia-bookletspreads-2.pdf

[23] L. Bakhmat, O. Babakina, Y. Belmaz, Journal of Physics: Conference Series 1840, 012050 (2021)

[24] I. Trubavina, S. Dotsenko, O. Naboka, M. Chaikovskyi, H. Meshko, Journal of Physics: Conference Series 1840, 012052 (2021)

[25] O. Bondarenko, S. Mantulenko, A. Pikilnyak, CEUR Workshop Proceedings 2257, 182 (2018)

[26] O. Spirin, V. Oleksiuk, N. Balyk, S. Lytvynova, S. Sydorenko, CEUR Workshop Proceedings 2393, 68 (2019)

[27] N. Holiver, T. Kurbatova, I. Bondar, E3S Web of Conferences 166, 10006 (2020)

[28] Y. Krylova-Grek, M. Shyshkina, CEUR Workshop Proceedings 2732, 1272 (2020)

[29] I. Clark, P. James, Blended learning: An approach to delivering science courses on-line, in Proceedings of the Blended Learning in Science Teaching and Learning: Symposium, 30 September 2005 (The University of Sydney, Sydney Australia, 2005), pp. 19-24

[30] I. Falconer, A. Littlejohn, Journal of Further and Higher Education 31, 41 (2007)

[31] C. Dziuban, J. Hartman, P. Moskal, Blended Learning (ECAR, Boulder, Colorado, 2004)

[32] C. Garnham, R. Kaleta, Teaching with Technology Today 8 (2002)

[33] I. Allen, J. Seamen, R. Garret, Blending In: The extent and Promise of Blended Education in the United States (The Sloan Consortium, Needham, MA, 2007), http://www.sloan-c.org/ publications/survey/pdf/Blending_In.pdf

[34] A. Picciano, Journal of Asynchronous Learning Networks 10, 95 (2006)

[35] D. Garrison, N. Vaughan, Blended learning in higher education: Framework, principles and guidelines (Jossey-Bass, San Francisco, 2008)

[36] A. Alammary, J. Sheard, A. Carbone, Australasian Journal of Educational Technology 39, 95 (2014)

[37] N. Vernadakis, M. Giannousi, V. Derri, M. Michalopoulos, E. Kioumourtzoglou, Pro- 
cedia Technology 1, 439 (2012)

[38] M.J. Kintu, C. Zhu, E. Kagambe, International Journal of Educational Technology in Higher Education 14, 7 (2017)

[39] O. Zhernovnykova, Scientific notes of the Berdyansk State Pedagogical University. Pedagogical sciences 2, 219 (2017)

[40] O.A. Zhernovnykova, L.Y. Peretiaha, A.V. Kovtun, M.V. Korduban, O.O. Nalyvaiko, N.A. Nalyvaiko, Information Technologies and Learning Tools 75, $170(2020)$
[41] A.I. Khan, N. ul Qayyum, M.S. Shaik, A.M. Ali, C.V. Bebi, I.J.Modern Education and Computer Science 9, 23 (2012)

[42] G.A. Ambrose, H.L. Chen, Theory into Practice 54, 317 (2015)

[43] A. Prokopenko, Y. Pidchasov, V. Moskalenko, S. Dotsenko, V. Lebedieva, Tekhnolohii dystantsiinoho navchannia: metodolohiia stvorennia ta suprovodu navchalnykh kursiv (Distance learning technologies: methodology of creating and maintaining training courses) (H.S. Skovoroda KhNPU, Kharkiv, 2019) 